\title{
Ethics teaching as an infectious activity
}

\author{
Henk ten Have ${ }^{1}$
}

Accepted: 11 August 2021 / Published online: 20 August 2021

(c) The Author(s), under exclusive licence to Springer Nature Switzerland AG 2021

The coronavirus has shown its capricious face over the last two years in all corners of the globe. Everyone is susceptible but vulnerability is very different, depending not only on individual factors but also on social and economic conditions. For some, infection results in severe illness, possible death, and sometimes long-term diminution of quality of life. Others hardly notice that they are infected; as asymptomatic carriers they may disseminate the virus widely. In the first contribution to this issue, Jonathan Beever and colleagues use epidemiological metaphors to examine the transmission of ethics in their teaching institution (Beever et al. 2021). Although it seems odd to compare ethics teaching with viral infection, in ordinary language we often use such analogies, speaking for example of an 'ínfectious' book or a 'viral' video. One can argue that epidemiological metaphors are inappropriate since ethics is not a lethal threat but rather a contribution to enhancing the quality of human life and the health of institutions. As such, it is more like a vaccine, protecting individuals and organizations against disruption and corruption of social life. On the other hand, the metaphors seem particularly relevant for the field of education which aims at transmissibility of knowledge, skills, and values. However, it is not just the infectiousness that counts but most of all its effects. The ultimate aim of education is transformative. Its goal is, in the words of Philip Jackson, "to effect beneficial changes in humans, not just in what they know and can do but, more important, in their character and personality, in the kind of persons they become" (Jackson 2012, 94). If this is the aim, education is fundamentally a moral enterprise. It is, what John Dewey has called, the manifestation of humankind's responsibility to conserve, transmit, rectify and expand the heritage of values we have received (Dewey 1934, 87). Within a university setting, ethics education invites students to participate in a specific professional community, grasping what is valuable in being a professional, emphasizing moral obligations towards colleagues and society, and shaping personal character.

Beever et al. (2021) present a fascinating in-depth study of how ethics teaching is distributed across the undergraduate curriculum and within disciplines in their university. They clarify the 'landscape of ethics': where ethics is taught and how ethics

Henk ten Have

tenhaveh@duq.edu

1 Center for Healthcare Ethics, Duquesne University, Pittsburgh, PA, USA 
teaching has evolved during the last decade. Certainly, the study is limited: it concerns only one large university in the United States, and does not focus on the quality and content of teaching programs. Nonetheless, it offers an exemplar of exposition: how and where students are exposed to ethics. Like an archaeologist excavating a particular site, the data are limited and localized but provide some ideas about the civilization to which the site belongs. The authors experience that it is difficult to get an exact overview of existing ethics courses (since it is not always clear what should count as an 'ethics course'), and that it is even more difficult to acquire information about course content (since ethics can be embedded in other courses, or is not clearly marked in course syllabi). Given these limitations, the findings are striking. First, the ethics component is small; only $2 \%$ of the offered 4000 undergraduate courses had an ethics component, while only more than half of these courses were actually taught. Second, there is no increase of ethics courses over ten years since 2008. These findings are remarkable because, as the authors notice, during this period the public and scientific debates on ethical issues have intensified, and professional codes of ethics and statements on responsible research conduct have multiplied. The third finding is even more striking: ethics teaching is very unevenly distributed among colleges, with hardly any ethics courses in the College of Nursing and the College of Medicine and Biomedical Sciences. The conclusion is that ethics is not a very infectious activity; it has limited distribution, thus a low reproduction number. The authors of the study modify this conclusion in suggesting that ethics has become an implicit component in many practices, particularly in nursing. Because it has become 'endemic,' it is not visible within course work. But the drawback is that for students the ethical dimension of their future profession is less identifiable. This is of course an hypothesis, and will require more detailed examination of courses themselves.

This interesting research calls for other studies in different institutions across the globe. While it is often reiterated that ethics should be a component of contemporary academic education, what precisely is its 'epidemiology' in university education?

\section{References}

Beever, Jonathan, Stephen M. Kuebler, and Jordan Collings. 2021. Where is ethics taught: An institutional epidemiology. International Journal of Ethics Education 6 (2): this issue.

Dewey, John. 1934. A common faith. New Haven: Yale University Press.

Jackson, Philip W. 2012. What is education? Chicago: The University of Chicago Press.

Publisher's note Springer Nature remains neutral with regard to jurisdictional claims in published maps and institutional affiliations. 